\title{
Production of transgenic mice expressing tumor virus A under ovarian-specific promoter 1 control using testis-mediated gene transfer
}

\author{
XINHUA CHEN $^{1}$, ZUJUAN ZHANG $^{1}$, XIAOHONG CHANG $^{1}$, YIDONG NIU ${ }^{2}$ and HENG CUI ${ }^{1}$ \\ ${ }^{1}$ Gynecologic Oncology Center and ${ }^{2}$ Laboratory Animal Center, Peking University People's Hospital, \\ Beijing 100044, P.R. China
}

Received May 16, 2013; Accepted November 21, 2013

DOI: $10.3892 / \mathrm{mmr} .2013 .1876$

\begin{abstract}
The aim of the present study was to produce transgenic mice expressing tumor virus A (TVA) in the ovary under ovarian specific promoter 1 (OSP1) control. A transgenic mouse model was established in which TVA, an avian retroviral receptor gene driven by OSP1, was selectively expressed in the ovary. A recombinant plasmid containing TVA cDNA and an OSP1 promoter was constructed. The DNA fragment was repeatedly injected into male mouse testes at multiple sites. At 4-7, 7-10 and 10-13 weeks following the final injection, two DNA-injected male mice were mated with four wild-type female mice to produce transgenic mice. The transgenic positive rate in mouse F1 offspring was $39.69 \%$. When the positive F1 individuals were mated with wild-type Imprinting Control Region mice $(\mathrm{PxW})$ or with positive $\mathrm{F} 1$ individuals ( $\mathrm{PxP})$, the $\mathrm{F} 2$ individuals had a transgenic rate of $12.44 \%$. The transgenic rates in the F1 offspring, produced following mating at the three time intervals, were 55.71 (39/70), 30.77 (4/13) and 18.75\% (9/48), respectively. The transgenic rates of the F2 offspring decreased with the age of the F1 offspring, from $26.67 \%$ when PxP were mated at 6-8 weeks of age to $6.52 \%$ when PxW were mated at 5-6 months of age. The results indicate a high efficiency of gene transfer to F1 offspring using testis-mediated gene transfer (TMGT). The transgenic rate in the F2 offspring was lower than that in the F1 offspring. The results reveal that TMGT is suitable for creating transgenic animals among F1
\end{abstract}

Correspondence to: Professor Heng Cui, Gynecologic Oncology Center, Peking University People's Hospital, 11 Xizhimen South Street, Xicheng, Beijing 100044, P.R. China

E-mail: cuiheng20@163.com

Professor Yidong Niu, Laboratory Animal Center, Peking University People's Hospital, 11 Xizhimen South Street, Xicheng, Beijing 100044, P.R. China

E-mail: niuyd07@yahoo.com.cn

Key words: transgenic mice, ovarian-specific promoter, testis-mediated gene transfer offspring. Semi-quantitative reverse transcription-polymerase chain reaction results showed that TVA was expressed in the mice ovaries. The results demonstrate the importance of using the replication-competent avian sarcoma-leukosis virus long terminal repeat with a splice acceptor-TVA system in ovarian tumorigenesis research.

\section{Introduction}

Since the 1980's, when transgenic mice were first produced by Gordon et al (1), transgenic biotechnology has been widely used to produce genetically modified animals for scientific and pharmaceutical research, animal husbandry and agricultural purposes (2-4). Over the past 30 years, scientists have continued to search for more efficient and easier transgenic methods. To date, various transgenic approaches have been developed, including pronuclear microinjection (PM), in vitro transfection of embryonic cells, particularly stem cells and embryonic stem cells, and the use of retroviruses and germ cells as vectors. Among the current methods, the use of retroviruses and germ cells as vectors for gene transfer are considered to be the most successful (5).

There are several germ cell-mediated gene transfer (GCMGT) methods, including male and female GCMGT (MGCMGT and FGCMGT, respectively). MGCMGT can be divided into sperm-mediated gene transfer (SMGT) (6) and testis-mediated gene transfer (TMGT) $(7,8)$, while FGCMGT is divided into oocyte-mediated gene transfer (9) and ovary-mediated gene transfer (10). Compared with the conventional PM approach, TMGT and ovary-mediated gene transfer (OMGT) are markedly cheaper and faster, and provide quick and effective delivery of genes to the target tissue (5). However, the transgenic offspring and mechanism of TMGT and OMGT require further investigation.

The replication-competent avian sarcoma-leukosis virus (ASLV) long terminal repeat with splice acceptor-tumor virus A (RCAS-TVA) system is one type of gene transfer method that is used extensively. Using this method, TVA, a receptor for the ASLV-A in avian cells, is transferred to mammalian cells. Subsequently, using RCAS, an avian retrovirus, the foreign DNA is transferred into the mammalian cells. RCAS-TVA has been widely used to study gene function, as 
well as to investigate gene therapy, developmental processes, tumorigenesis and diseases (11-19).

To apply the RCAS-TVA system in gene research, the production of TVA transgenic animals is required. The key elements involved are the tissue- or organ-specific promoters that determine the specific expression of TVA in target organs, tissues or cells. To examine the effect of certain oncogenes on ovarian tumorigenesis, the present study produced transgenic mice that expressed TVA in their ovaries. Of the promoters that are able to control gene expression in the ovary, including $\beta$-actin (20), keratin (21) and ovarian-specific promoter 1 (OSP1) $(22,23)$, OSP1 is accepted as the most specific (20-23); therefore, OSP1 was selected to control TVA expression in the mice ovaries in the present study.

In this study, transgenic mice expressing TVA under the control of OSP1 in their ovaries were produced. The results confirmed that a TVA gene with an OSP1 promoter could be transferred to the eggs via the sperm during fertilization, whereby transgenic F1 and F2 individuals were produced. The transgenic nature of the offspring was verified using polymerase chain reaction (PCR), southern blot hybridization and semi-quantitative reverse transcription (RT)-PCR. The results confirmed that a foreign gene is capable of being transferred to a transgenic F1 animal genome and subsequently to F2 descendants.

\section{Materials and methods}

Animals. Six-week-old adult Imprinting Control Region (ICR) mice were purchased from the Laboratory Animal Center of the Academy of Military Medical Science (Beijing, China) and housed in our laboratory's specific-pathogen free animal unit (Peking University People's Hospital, Beijing, China), under controlled temperature $\left(20-26^{\circ} \mathrm{C}\right)$ and humidity $(40-70 \%)$, with a 12-h light/dark cycle. The experimental protocol for the use of mice in this study was approved by the Animal Care and Use Committee at Peking University People's Hospital.

Productionofvectors. The plasmid,pUC18-MMTV-TVA-MP-1 was provided by Professor Li Yi (Baylor College of Medicine, Houston, TX, USA). The plasmid contained the MMTV promoter, TVA protein cDNA and a mouse MP-1 signal. A novel plasmid, pUC18-OSP1-TVA-MP-1, was constructed by replacing the MMTV promoter with the OSP1 promoter. The restriction map of the vector pUC18-OSP1-TVA-MP-1 is shown in Fig. 1. The novel plasmid DNA was prepared by using a plasmid extraction kit (Tiangen Biotech Co., Ltd., Beijing, China), accoring to the manufacturer's instructions. Prior to gene transfer, the plasmid was linearized by digestion with HindIII and $\mathrm{XbaI}$ (Fermentas, Vilnius, Lithuania). The 2.287-kb DNA fragment containing OSP1, TVA and MP-1 cDNA was purified prior to injection.

The TVA sequence was as follows: gtacctaaaa caagttgagt ggaagattcc actcaaggac aaaaaagaa aatgggggaa tgaaagaccc cctcccagaa agggaattgt acaagcccaa gtccctcaaa tatagaagta aaaagtaagt ttttagatat gtgggacaag ctgacccatc atttagacga aacagaccag aaaagaaaac aaaatgcaga aaccagacta aattatgggc actgctccat gggecacctg acaggaaaa gaaaaagtcc ctgaccecc ggaagccetg accaccatgt acttttgct aactcactgt tatgattata gccaaaatag gtaacataca cgtatgcetc atttactcca ccaatcacat

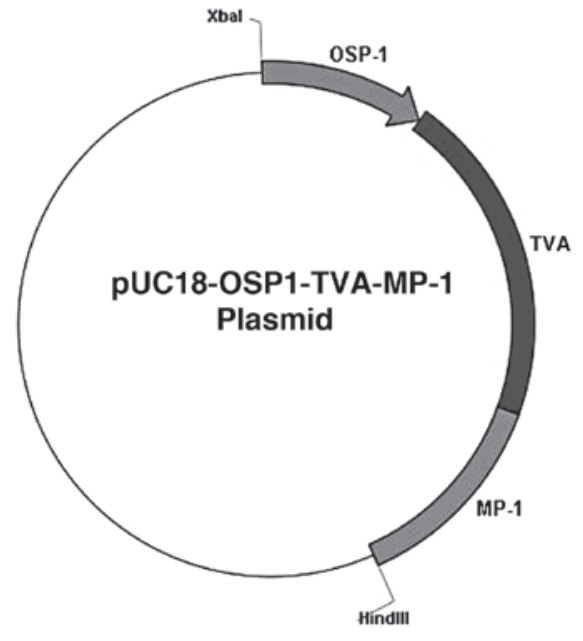

Figure 1. Restriction map of the vector pUC18-OSP1-TVA-MP1. OSP1, ovarian-specific promoter 1; TVA, tumor virus A (an avian retroviral receptor gene); MP-1, mouse protamine-1 poly(A) signal.

ccetgtaacc atgeatctgc ttctgtaagc ctgettctgc tecccaaaat actataaaaa gcceaccetg getctgctag gegcgecagg atcc.

The OSP1 sequence was as follows: c agaggtacct aaaacaagtt gagtggaaga ttccactcaa ggacaaaaag aaaatggggg aatgaaagac cctctcccag aaagggaatt gtacaagccc caaggecctc aactatagaa gtaataaata agtgttagat atgtggggca agctgaccca tcatttaggc ggaacaggcc agaaaaggaa ccccaaatgc agaaaccaga ctaaattatg ggccetgctc catgggecac ctggcaggaa aaagaaaaag tccetgaccc cccggaagec ctgaccacca tgtactttt getaactcac tgttatgatt atagcccaaa taggtaacat acacgtatgc ctcatttact ccaccaatca catccetgta accattcatc tgettctgta agcetgettc tgctccecca aatactataa aaagcccacc ctggctctge taggegegce agtct.

Preparation of gene suspensions. N-[1-(2,3-dioleoyloxy) propyl]-N,N,N-trimethylammonium methylsulfate (DOTAP) liposomal transfection reagent (Roche Diagnostics, Mannheim, Germany) was used to deliver the foreign DNA. The DNA-DOTAP solution was prepared by mixing solution A [20 $\mu 1$ (1 g/l) DOTAP diluted in HBS (Dingguo Changsheng Biotech Co., Ltd., Beijing, China; $20 \mathrm{mmol} / \mathrm{l}$ Hepes and $150 \mathrm{mmol} / \mathrm{l} \mathrm{NaCl}, \mathrm{pH} 7.4$ ) to obtain $30 \mu \mathrm{l}]$ with solution B (10 $\mu \mathrm{g}$ DNA diluted with HBS to obtain $30 \mu \mathrm{l})$. The mixture was incubated for $20 \mathrm{~min}$ at room temperature (24).

Preparation of TMGT males. Two mature male ICR mice, aged 6-8 weeks, were anesthetized with pentobarbital (New Asia Pharmaceutical Co., Ltd., Shanghai, China) at $0.1 \mathrm{mg} / \mathrm{g}$ intraperitoneal injection (IP), and $60 \mu 1$ DOTAP-DNA solution was directly injected via the scrotum into the two testes of each mouse with a $31 \mathrm{G}$ needle attached to a $0.5-\mathrm{ml}$ disposable syringe. Half of the DNA-DOTAP solution(30 $\mu \mathrm{l})$ was applied to each testis in an injection. Each testis was injected at three to four different random but separated sites. Following injection, the needle was slowly removed from the testis and ketorolac (Pharmacy of Peking University People's Hospital, Beijing, China) was used at $0.5 \mathrm{mg} / \mathrm{kg}$ IP once daily to ease pain. Each mouse received three sets of injections of the DNA-DOTAP solution, and the interval between each set of injections was 3-5 days. 
Table I. Transgene statistics of F1 offspring following copulation between sexually mature male TMGT-injected mice and wild-type female mice.

Average

Time after TMGT injection when mating (weeks)

No. of offspring

No. of transgenic offspring
Positive rate

(\%)

$55.71^{\mathrm{a}}$

30.77

$18.75^{\mathrm{a}}$
Positive rate

(\%)

\begin{tabular}{lcccc}
\hline $4-7$ & 70 & 39 & $55.71^{\mathrm{a}}$ & 39.69 \\
$7-10$ & 13 & 4 & 30.77 \\
$10-13$ & 48 & 9 & $18.75^{\mathrm{a}}$
\end{tabular}

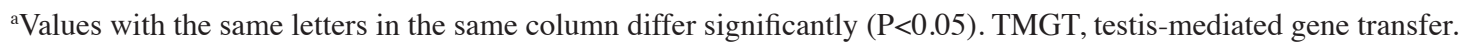

Production of transgenic mice. At 4-7, 7-10 and 10-13 weeks following the final testis injection, each injected male mouse was mated with two wild-type estrus females to produce F1 offspring. Once the F1 offspring matured, F2 offspring were produced. The matings for the production of F2 offspring occurred between $\mathrm{F} 1$ transgenic positive $(\mathrm{P})$ individuals and either $\mathrm{F} 1$ transgenic positive $(\mathrm{PxP})$ individuals or non-transgenic (W) mice (PxW). Such matings occurred when the F1 offspring were 6-8 weeks and 5-6 months old. In total, four groups of F2 offspring were produced.

\section{Identification of transgenic individuals}

Extraction of genomic DNA. Genomic DNA was isolated from three-week-old offspring by dissolving tail tissue in a mixture of $0.5 \mathrm{ml}$ of $10 \mathrm{mmol} / \mathrm{L}$ EDT, $0.5 \% \mathrm{SDS}$ and $50 \mu \mathrm{l}$ of $10 \mathrm{~g} / \mathrm{l}$ proteinase $\mathrm{K}$ (Tiangen Biotech Co., Ltd.). The mixture was incubated at $56^{\circ} \mathrm{C}$ overnight with gentle shaking. Once the undigested materials were removed with a low-speed centrifuge at 9,660 x $\mathrm{g}$ for $30 \mathrm{sec}$, the mixture was extracted with phenol/chloroform and precipitated with ethanol, and the DNA was dissolved in double-distilled $\mathrm{H}_{2} \mathrm{O}$.

$P C R$ analysis. The primers used were as follows: Antisense: 5'-CTG CTG CCC GGT AAC GTG ACC GG-3' and sense: 5'-GCC CTG GGG AAG GTC CTG CCC-3' for TVA cDNA. The $20 \mu \mathrm{l}$ PCR system contained $1 \mu \mathrm{g}$ genomic DNA, $200 \mu \mathrm{mol} / 1 \mathrm{dNTPs}, 2 \mathrm{mmol} / 1 \mathrm{MgCl}_{2}, 1.2 \mathrm{U}$ Taq DNA polymerase (Tiangen Biotech Co., Ltd.) and 10 pmol of each primer. The PCR involved denaturing at $94^{\circ} \mathrm{C}$ for $5 \mathrm{~min}$, then 30 cycles of $94^{\circ} \mathrm{C}$ for $30 \mathrm{sec}, 73^{\circ} \mathrm{C}$ for $30 \mathrm{sec}$ and $72^{\circ} \mathrm{C}$ for $50 \mathrm{sec}$, with elongation at $72^{\circ} \mathrm{C}$ for $5 \mathrm{~min}$. The anticipated size of the amplified fragment was $477 \mathrm{bp}$ for TVA cDNA. The PCR products were electrophoresed on a $1 \%$ agarose gel.

Southern blot analysis. Southern blot hybridization of genomic DNA was performed to determine the rate of occurrence of transgenic positive individuals. Genomic DNA $(20 \mu \mathrm{g})$ isolated from $\mathrm{F} 1$ transgenic individuals was digested to completion with HindIII and $X b a I$ restriction enzymes, resolved on $0.6 \%$ agarose gel and transferred to a nylon membrane. The nylon membrane was maintained at $80^{\circ} \mathrm{C}$ for $2 \mathrm{~h}$ to fix the DNA, then prehybridized at $42^{\circ} \mathrm{C}$ for $30 \mathrm{~min}$ in a prehybridization solution (Roche Diagnostics), followed by hybridization with digoxigenin-11-dUTP (Roche Diagnostics) -labeled TVA cDNA at $42^{\circ} \mathrm{C}$ for $16 \mathrm{~h}$, according to the manufacturer's instructions.

Semi-quantitative RT-PCR. Total RNA was extracted from the ovaries of F1 mice using the total RNA extrac- tion kit (Tiangen Biotech Co., Ltd.). First-strand cDNA was synthesized from $1 \mu \mathrm{g}$ total RNA treated with DNase (Tiangen Biotech Co., Ltd.) that was isolated from the ovaries of the TVA-positive mice. An aliquot of the first-strand synthesized cDNA was then utilized for TVA PCR amplification. The primers used were the same as listed previously. The sample loading and cycling conditions used for the subsequent semi-quantitative RT-PCR reactions were as described previously. GAPDH was amplified as a housekeeping gene control. The aforementioned TVA primers were used, and those used for GAPDH cDNA were as follows: Antisense: 5'-AAT CCC ATC ACC ATC TTC C-3' and sense: 5'-CAT CAC GCC ACA GTT TCC-3'.

Statistical analysis. The $\chi^{2}$-test was used to statistically analyze the data. Categorized variables were described as percentages and analyzed using the $\mathrm{r}$ by $\mathrm{c} \chi^{2}$ test. The statistical analyses were performed with SPSS for Windows (version 13.0; SPSS Inc., Chicago, IL, USA). A two-tailed $\mathrm{P}<0.05$ was considered to indicate statistically significant differences.

\section{Results}

Detection of TVA expression in F1 mice by PCR and southern blotting. The group of TMGT-treated mice, two TGMT males and four wild-type females, produced a total of 131 pups. The transgenic individuals in the F1 cohort were identified based on PCR amplification of a 477-bp TVA product (Fig. 2). Analysis of the results indicated that the TVA-positive rates in the F1 offspring produced following parental mating at three stages (4-7, 7-10 and 10-13 weeks following the final testis injection) were 55.71 (39/70), 30.77 (4/13) and $18.75 \%$ (9/48), respectively (Table I). There was a statistically significant difference between the positive rates in the first and third stages $(\mathrm{P}<0.05)$. The average positive rate in the F1 group was $39.69 \%(52 / 131)$. The results of the southern blot hybridization were consistent with those of the PCR analysis (Fig. 3). The male to female ratio in the transgenic progeny was $\sim 1: 1$ and the mean number of pups born per litter was 10.08 (131/13), with a newborn pup (three weeks old) survival rate of $93.13 \%$ (122/131).

Detection of TVA expression in transgenic mice by semi-quantitative RT-PCR. Semi-quantitative RT-PCR analysis of TVA expression was performed using a GAPDH internal control. In the majority of the TVA transgenic mice, the predicted 


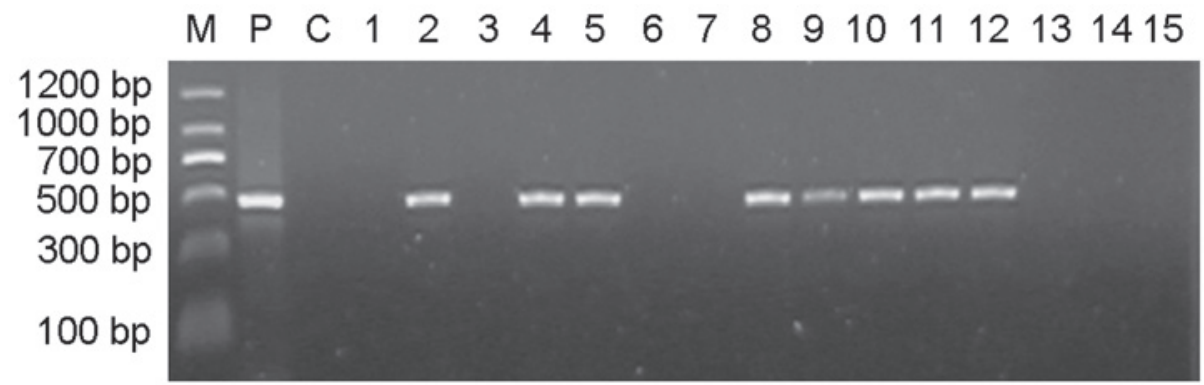

Figure 2. Image of $1 \%$ agarose gel from PCR analysis for TVA cDNA detection in F1 offspring. M, molecular mass marker (DNA Marker II); P, positive control (TVA cDNA); C, negative control; 1-15, DNA samples from 15 F1 transgenic mice. PCR, polymerase chain reaction; TVA, tumor virus A.

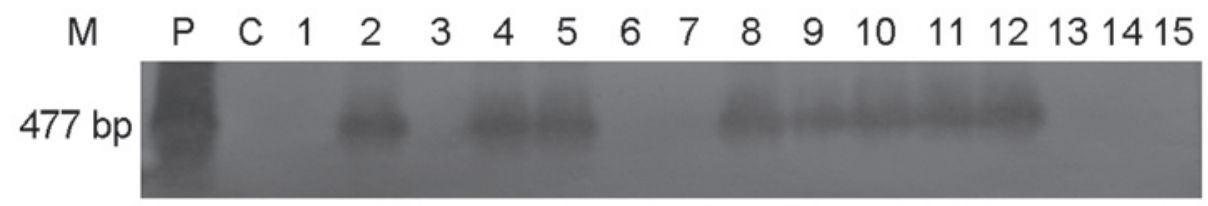

Figure 3. Image of southern blot hybridization results using digoxigenin-11-dUTP-labeled TVA cDNA as a probe. M, molecular mass marker (DNA Marker II); $\mathrm{P}$, positive control (TVA cDNA); C, negative control; 1-15, DNA samples from $15 \mathrm{~F} 1$ transgenic mice. TVA, tumor virus A.

A $\begin{array}{llllllllllllllllllll}M & P & C & 1 & 2 & 3 & 4 & 5 & 6 & 7 & 8 & 9 & 10 & 11 & 12 & 13 & 14 & 15\end{array}$ $\begin{aligned} & 1200 \mathrm{bp} \\ & 1000 \mathrm{bp} \\ & 700 \mathrm{bp} \\ & 500 \mathrm{bp} \\ & 300 \mathrm{bp} \\ & 100 \mathrm{bp}\end{aligned}$

B

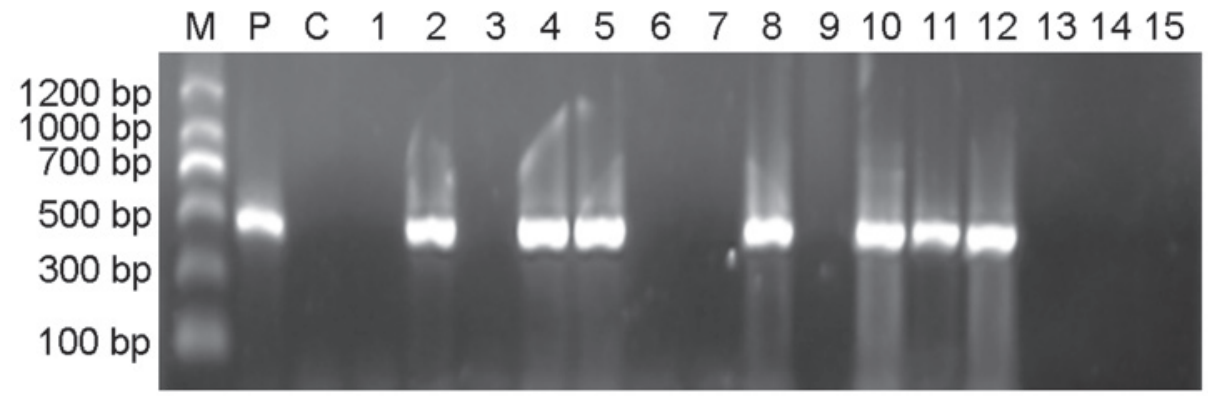

Figure 4. Image of 1\% agarose gel from RT-PCR analysis for TVA cDNA in F1 offspring. M, molecular mass marker (DNA Marker II); C, negative control; 1-15, DNA samples from 15 F1 transgenic mice. (A) Detection of GAPDH mRNA in F1 transgenic mice. P, positive control (DNA of mouse). (B) Detection of TVA mRNA in F1 transgenic mice. P, positive control (TVA cDNA). RT-PCR, reverse tanscription-polymerase chain reaction; TVA, tumor virus A.

477-bp TVA fragment was amplified. In each of those cases, the predicted 382-bp fragment from a GAPDH internal control was amplified (Fig. 4). The transgenic positive rate in the F1 group by semi-quantitative RT-PCR analysis was $34.35 \%$.

Production of F2 generation mice. To investigate the pattern of foreign gene transmission into a subsequent generation, F1 transgenic positive individuals were mated with F1 transgenic positive individuals $(\mathrm{PxP})$ or with non-transgenic mice $(\mathrm{PxW})$ when they were 6-8 weeks (early) and 5-6 months (late) old. The transgenic status of the obtained F2 offspring was analyzed by PCR and southern blot hybridization.

The analyses indicated that the transgenic positive rates in the F2 group in the four groups (early PxW, early PxP, late PxW and late PxP groups) were 9.52 (6/63), 26.67 (4/15), 6.52 (3/46) and 15.94\% (11/69), respectively (Table II). The positive rates in the early and late groups were $12.82(10 / 78)$ and $12.17 \%(14 / 115)$, respectively $(\mathrm{P}>0.05)$. The positive rates in PxW groups and PxP groups were 8.26 (9/109) and $17.86 \%(15 / 84)$, respectively $(\mathrm{P}<0.05)$. 
Table II. Transgene statistics of F2 offspring.

\begin{tabular}{|c|c|c|c|c|c|c|c|}
\hline Group & $\begin{array}{l}\text { Age of the } \\
\text { mice when } \\
\text { mating }\end{array}$ & $\begin{array}{l}\text { No. of } \\
\text { offspring }\end{array}$ & $\begin{array}{c}\text { No. of } \\
\text { transgenic } \\
\text { offspring }\end{array}$ & $\begin{array}{c}\text { Positive } \\
\text { rate } \\
(\%)\end{array}$ & $\begin{array}{c}\text { No. of } \\
\text { offspring }\end{array}$ & $\begin{array}{c}\text { No. of } \\
\text { transgenic } \\
\text { offspring }\end{array}$ & $\begin{array}{l}\text { Average } \\
\text { positive } \\
\text { rate }(\%)\end{array}$ \\
\hline \multirow[t]{2}{*}{ PxW } & 6-8 weeks & 63 & 6 & $9.52^{\mathrm{a}}$ & \multirow[t]{2}{*}{109} & \multirow[t]{2}{*}{9} & \multirow[t]{2}{*}{$8.26^{c}$} \\
\hline & 5-6 months & 46 & 3 & $6.52^{\mathrm{b}}$ & & & \\
\hline \multirow[t]{2}{*}{$\mathrm{PxP}$} & 6-8 weeks & 15 & 4 & $26.67^{a}$ & \multirow[t]{2}{*}{84} & \multirow[t]{2}{*}{15} & \multirow[t]{2}{*}{$17.86^{\mathrm{c}}$} \\
\hline & 5-6 months & 69 & 11 & $15.94^{\mathrm{b}}$ & & & \\
\hline
\end{tabular}

${ }^{\mathrm{a}-\mathrm{c}}$ Values with the same letters in the same column differ significantly $(\mathrm{P}<0.05)$. $\mathrm{P}$, transgenic positive; W, non-transgenic positive.

The positive rate in the entire F2 group was $12.44 \%$ (24/193), while that in the entire F1 group was $39.69 \%$ (52/131). The F2 group's positive rate was significantly lower than that of the F1 group $(\mathrm{P}<0.05)$. The results of the southern blot hybridization analysis were consistent with the PCR-based results.

\section{Discussion}

During the past few decades, TMGT has been performed using surgical incisions to expose testis tubules. Foreign DNA was then injected into the animal's seminiferous tubules using microinjection. Injected foreign DNA may be transferred into eggs via sperm and subsequently expressed in the progeny $(25,26)$. In the present study, the foreign DNA was injected by syringe, on three occasions at multiple sites, into the male mice testes without incision. This renders the procedure easier and decreases the potential for injury to the mice.

In the study, the transgenic rates of F1 offspring decreased with the time elapsed following TMGT treatment. The same phenomenon was observed in the F2 offspring, with the F2 transgenic rate decreasing with the age of the F1 parents. The observed overall F1 transgenic positive rate of $39.69 \%$ is concordant with the result of $41 \%$ obtained by He et al (24) in a study on F1 offspring. However, our F2 transgenic positive rate was $12.44 \%$, which is significantly lower than the rate of $37 \%$ obtained by He et al in a study on F2 offspring (24). Sato et al (27) also obtained F2 transgenic-positive animals. However, Shen et al (26) and Valenzuela et al (28) did not identify transgene-positive individuals in an $\mathrm{F} 2$ generation. We hypothesize that the transgenic positive rate in F2 offspring is associated with the age at which the F1 parents are mated; the younger the F1 parent, the higher the F2 transgenic positive rate; when the $\mathrm{F} 1$ parent ages, the $\mathrm{F} 2$ transgenic positive rate decreases.

A number of studies investigating TMGT have suggested a possible TMGT mechanism: When foreign DNA is injected directly into a testis, it is rapidly transferred to epididymal spermatozoa, which subsequently transfer the DNA to oocytes through fertilization (29). In addition, the foreign gene is transferred to sperm during the spermatogenic processes from spermatogonia to mature spermatozoa $(25,26,30)$. Moreover, the foreign DNA may exist as integrated and/or non-integrated types in sperm cells (5). Regardless, the TMGT mechanism has not been investigated extensively. Sato et al (27) suggested that TMGT via epididymal spermatozoa was a possible method for an in vivo gene transfer system. A number of studies have reported that the TMGT method allows the foreign gene to be expressed over a long period of time, as intra-testis cells and sexually mature sperm are able to carry a large number of foreign genes (31-33).

Spermatozoa are produced in the seminiferous tubules of the testes, where they emerge initially as spermatogonia and then undergo mitosis to become type A or type B spermatogonia. Type B spermatogonia become primary spermatocytes that undergo one meiotic division to become secondary spermatocytes and another to become spermatids. Type A spermatogonia are the only immortalized diploid cells that are reproduced in adult male animals, including mice, and they have a high self-renewal capacity and pluripotent potential $(34,35)$. On that basis, and following consideration of the results of the present study along with those of Shen et al (26) and Valenzuela et al (28), it was suggested that the TMGT mechanism may include additional components. Once a foreign DNA and liposome (DOTAP) complex is injected directly into the testis, all cells that have contact with that complex, not only spermatids at different development stages, but also the two types of spermatogonia are considered to be transfected with foreign DNA. Following this transfection, the original genome returns to stability by clearing the foreign DNA step-by-step; thus, the transgenic rate decreases with time.

It was proposed that the reasons transgenic rates decrease with time are associated with the state of foreign DNA. The foreign DNA may exist as episomal and integrated genes. Following mitosis, novel cells inherit the integrated foreign DNA but the episomal foreign DNA is diluted and lost. Thus, this may be the reason for the low transmission rates in the F2 offspring of the present study. It may be that the level of episomal foreign DNA is markedly greater than the integrated DNA in the present study. It is also hypothesized that the integrated gene may be unstable as it is not possible to control the integration position in the chromosome. This will accelerate the rate at which the integrated gene is lost from the genome. We aim to use the transposons to improve the affection of gene transfer. It has been proposed that the integrated gene may be more stable when using the transposons at the special integration position in the chromosome. The mechanism and transgenic affection of TMGT are complex. Considerable investigation is required to reveal the exact mechanism.

The results of the present study demonstrate that the TMGT method does not require expensive equipment or specialized 
skills. It is also simpler, less costly and more convenient than the PM and OMGT methods and techniques involving in vitro transfection of embryonic cells, stem cells and embryonic stem cells. For the method of the present study, a needle and a plastic syringe were sufficient for delivery of the foreign DNA.

In the present study, total RNA was extracted from transgenic mice ovaries. Following semi-quantitative RT-PCR of the RNA, TVA-positive strands were observed. Thus, TVA is capable of being expressed in the ovary under the control of OSP1; a result that is in concurrent with those of Hamilton et al $(22,23)$.

In conclusion, the present study showed that an avian TVA gene may be introduced into ICR mice by TMGT. The positive transgenic rate was high in the F1 offspring (39.69\%); however, in the $\mathrm{F} 2$ offspring, the positive transgenic rate was $12.44 \%$, indicating that the foreign DNA may be partially lost. The TMGT method is suitable for creating transgenic animals $(24,36)$ and is a reliable method for transgenesis. The results of the present study show that female transgenic mice are able to express TVA under the control of OSP1, indicating the importance of the RCAS-TVA technique for ovarian tumorigenesis research.

\section{Acknowledgements}

This study was supported by the National Natural Science Foundation of China (grant no. 81172454), Research and Development Fund, Peking University People's Hospital (grant no. RDB2008-16). The authors would like to thank Professor Li Yi of Baylor College of Medicine (Houston, TX, USA), for kindly providing the plasmid pUC18-MMTV-TVA-MP-1.

\section{References}

1. Gordon JW, Scangos GA, Plotkin DJ, Barbosa JA and Ruddle FH: Genetic transformation of mouse embryos by microinjection of purified DNA. Proc Natl Acad Sci USA 77: 7380-7384, 1980.

2. Chan AW: Transgenic animals: current and alternative strategies. Cloning 1: 25-46, 1999.

3. Mullins LJ and Mullins JJ: Transgenesis in the rat and larger mammals. J Clin Invest 97: 1557-1560, 1996.

4. Wall RJ: New gene transfer methods. Theriogenology 57: 189-201, 2002.

5. Niu Y and Liang S: Progress in gene transfer by germ cells in mammals. J Genet Genomics 35: 701-714, 2008.

6. Moreira PN, Pozueta J, Pérez-Crespo M, Valdivieso F, Gutiérrez-Adán A and Montoliu L: Improving the generation of genomic-type transgenic mice by ICSI. Transgenic Res 16: 163-168, 2007.

7. Ivics Z, Izsvák Z, Medrano G, Chapman KM and Hamra FK: Sleeping Beauty transposon mutagenesis in rat spermatogonial stem cells. Nat Protoc 6: 1521-1535, 2011.

8. Dhup S and Majumdar SS: Transgenesis via permanent integration of genes in repopulating spermatogonial cells in vivo. Nat Methods 5: 601-603, 2008.

9. Lois C, Hong EJ, Pease S, Brown EJ and Baltimore D: Germline transmission and tissue-specific expression of transgenes delivered by lentiviral vectors. Science 295: 868-872, 2002.

10. Yang SY, Wang JG, Cui HX, et al: Efficient generation of transgenic mice by direct intraovarian injection of plasmid DNA. Biochem Biophys Res Commun 358: 266-271, 2007.

11. Bu W, Chen J, Morrison GD, et al: Keratin 6a marks mammary bipotential progenitor cells that can give rise to a unique tumor model resembling human normal-like breast cancer. Oncogene 30: 4399-4409, 2011.

12. Du Z and Li Y: RCAS-TVA in the mammary gland: an in vivo oncogene screen and a high fidelity model for breast transformation? Cell Cycle 6: 823-826, 2007.
13. Du Z, Podsypanina K, Huang S, et al: Introduction of oncogenes into mammary glands in vivo with an avian retroviral vector initiates and promotes carcinogenesis in mouse models. Proc Natl Acad Sci USA 103: 17396-17401, 2006.

14. Hambardzumyan D, Amankulor NM, Helmy KY, Becher OJ and Holland EC: Modeling adult gliomas using RCAS/t-va technology. Transl Oncol 2: 89-95, 2009.

15. Lewis BC, Klimstra DS and Varmus HE: The c-myc and PyMT oncogenes induce different tumor types in a somatic mouse model for pancreatic cancer. Genes Dev 17: 3127-3138, 2003.

16. Loftus SK, Larson DM, Watkins-Chow D, Church DM and Pavan WJ: Generation of RCAS vectors useful for functional genomic analyses. DNA Res 8: 221-226, 2001.

17. Niu Y and Liang SL: Mammalian models based on RCAS-TVA technique. Zoological Res 3: 335-345, 2008.

18. Reddy JP and Li Y: The RCAS-TVA system for introduction of oncogenes into selected somatic mammary epithelial cells in vivo. J Mammary Gland Biol Neoplasia 14: 405-409, 2009.

19. Sausville J, Molinolo AA, Cheng X, et al: RCAS/SCL-TVA animal model allows targeted delivery of polyoma middle $\mathrm{T}$ oncogene to vascular endothelial progenitors in vivo and results in hemangioma development. Clin Cancer Res 14: 3948-3955, 2008.

20. Orsulic S: An RCAS-TVA-based approach to designer mouse models. Mamm Genome 13: 543-547, 2002.

21. Xing D and Orsulic S: A genetically defined mouse ovarian carcinoma model for the molecular characterization of pathway-targeted therapy and tumor resistance. Proc Natl Acad Sci USA 102: 6936-6941, 2005.

22. Bao R, Selvakumaran M and Hamilton TC: Targeted gene therapy of ovarian cancer using an ovarian-specific promoter. Gynecol Oncol 84: 228-234, 2002.

23. Selvakumaran M, Bao R, Crijns AP, Connolly DC, Weinstein JK and Hamilton TC: Ovarian epithelial cell lineage-specific gene expression using the promoter of a retrovirus-like element. Cancer Res 61: 1291-1295, 2001.

24. He X, Qi B, Liu G, Yu W and Chen Q: A novel method to transfer gene in vivo system. Prog Biochem Biophys 33: 685-690, 2006.

25. Chang KT, Ikeda A, Hayashi K, et al: Production of transgenic rats and mice by the testis-mediated gene transfer. J Reprod Dev 45: 29-36, 1999.

26. Shen W, Li L, Pan Q, Min L, Dong H and Deng J: Efficient and simple production of transgenic mice and rabbits using the new DMSO-sperm mediated exogenous DNA transfer method. Mol Reprod Dev 73: 589-594, 2006.

27. Sato M, Ishikawa A and Kimura M: Direct injection of foreign DNA into mouse testis as a possible in vivo gene transfer system via epididymal spermatozoa. Mol Reprod Dev 61: 49-56, 2002.

28. Valenzuela M, Relloso M and Esponda P: In vivo transfection of the mouse vas deferens. J Exp Zool 293: 532-540, 2002.

29. Celebi C, Auvray P, Benvegnu T, Plusquellec D, Jégou B and Guillaudeux T: Transient transmission of a transgene in mouse offspring following in vivo transfection of male germ cells. Mol Reprod Dev 62: 477-482, 2002.

30. Yonezawa T, Furuhata Y, Hirabayashi K, Suzuki M, Takahashi M and Nishihara M: Detection of transgene in progeny at different developmental stages following testis-mediated gene transfer. Mol Reprod Dev 60: 196-201, 2001.

31. Coward K, Kubota H, Hibbitt O, McIlhinney J, Kohri K and Parrington J: Expression of a fluorescent recombinant form of sperm protein phospholipase $C$ zeta in mouse epididymal sperm by in vivo gene transfer into the testis. Fertil Steril 85 (Suppl 1): 1281-1289, 2006.

32. Hibbitt O, Coward K, Kubota H, et al: In vivo gene transfer by electroporation allows expression of a fluorescent transgene in hamster testis and epididymal sperm and has no adverse effects upon testicular integrity or sperm quality. Biol Reprod 74: 95-101, 2006.

33. Kubota H, Hayashi Y, Kubota Y, Coward K and Parrington J: Comparison of two methods of in vivo gene transfer by electroporation. Fertil Steril 83 (Suppl 1): 1310-1318, 2005.

34. Gilbert SF: Developmental Biology. 8th edition. Sinauer Associates, Sunderland, MA, pp613-646, 2006.

35. Schlatt S: Spermatogonial stem cell preservation and transplantation. Mol Cell Endocrinol 187: 107-111, 2002.

36. Ju H, Bai L, Ren H, Mu Y, Yang S and Li K: Production of transgenic mice by type-A spermatogonia-mediated gene transfer. Agri Sci Chin 10: 431-437, 2011. 